\title{
Diagnóstico de partida para diseñar un modelo de proyecto que permita implantar el proceso de inteligencia empresarial en las empresas del grupo de diseño e ingeniería de la construcción en Cuba
}

\section{Diagnosis of initial data to design a project model enabling the implementation of a business intelligence process for design and construction engineering companies in Cuba}

\author{
Julio García*1, José A. Macías** \\ * Grupo Empresarial de Diseño e Ingeniería de la Construcción. CUBA \\ ** Instituto Superior Politécnico "José Antonio Echeverría”, UNAICC de Matanzas. CUBA
}

Fecha de recepción: 25/ 08/2009 Fecha de aceptación: 01/ 03/ 2010

Resumen 
Project Management is an absolute requirement to approach the implementation of new technologies and processes for construction sector in Cuba, since the continuous attempts to develop them, in an empirical or traditional way, have only conducted to partial results or to failures of outlined goals.

Several factors determine whether Project Management is required, however in the case of design and implementation of a Business Intelligence Process for the design and engineering of construction companies, such factors are present. Therefore, it was decided that this process fits this $M$ anagement system, because of the advantages involved for a modern organization to get orientated towards projects (H eredia R., 1999), provided that:

- Projects help to spread support and comprehension in all directions.

- This new activity will impact the members of all the organization.

- The project will be benefited from all specialization diversity, basis and experiences.

- It enables the optimization of Q uality, Costs and Project deadline.

There are a growing number of organizations in the world that are basing their management system on the knowledge and use of products from business intelligence, thus increasing their competitiveness levels. In Cuba only few organizations have lead this way, however, the ones that have, today show outstanding results that place them among the most advanced in their market specialty in the world.

Cuba, also involved in the present and turbulent global environment, has been affected by events such as the socialism fall down, the globalization process of international economy, the reinforcement of North American blockade together with a growing role of technology and services sectors, which have forced Cuba to develop an economical restructuration policy, where the assimilation of modern management methods and techniques becomes a must.

In N ovember 1997 the "Economical Resolution" was issued (Periódico Granma, 1997) that outlined one of its main lineaments: "Investment policy and its effectiveness are crucial for the efficiency increase". Therefore, it is necessary to meet the international regulations in all respects of conception, projection, construction and implementation of investment scope... 
The use of modern business administration techniques appropriate to our characteristics, based on the best and most advanced contemporary practices, as well as a wide use of technology, information and telecommunication services, must be a priority in our country in order to guarantee highest efficiency of productive processes management. Financial, advisory and services, together with technical professional services shall undergo a strong development in our national territory and in other countries.

The Construction sector has been affected by the financial contraction during recent years and faces the challenge of finding solutions to finance the minimum requirements of this sector in a short time period. Solutions must be achieved by means of effectiveness, efficiency and internal savings, so as to compete in the international market (Rodríguez Peña, 1998). Therefore, counting with Business Intelligence systems will allow us to face a strong competition in this sector by using the intelligence products obtained.

Over recent years, Cuban Design and Engineering companies methodologically grouped in the Projects Front have been focused in the process of pushing forward business improvement, 18 out of them associated to the Design and Construction Engineering Business Group (GEDIC) of the Construction Ministry intend to conduct this research. Such entities represent a leading sector for the implementation of this new Cuban Management and Business Administration System, having as a latent need the requirement of achieving higher goals. Besides, this is a sector sensitive to any development strategy in the country, where an investment process is required, so most companies aspire to acquire new management techniques to provide services for the national construction market and to launch an increasing number of services into the international market. of course above is equivalent to count with Project Models that facilitate the incorporation of a Business Intelligence Process $(\mathrm{BI})$ to their daily routine as soon as possible.

This paper presents the results of a diagnosis conducted by18 entities of Design and Construction Engineering Business Group (GEDIC), with the purpose of sharing the initial data situation of this project approach for the implementation of a Business Intelligence Process in management systems in Cuban design and engineering sector, which will provide them with the ability to capture and analyze data, in an organized and systematic way, 
to control, obtain and broadcast relevant information about external environment and internal conditions thus delivering a global vision of economical, financial, historical, regulatory, political, social and technological aspects that allows the creation of a solid knowledge for decision making processes, where Strategic Management will have the best chances for a correct implementation, making a contribution to the proper compliance of outlined goals by reducing potential risk margin and increasing competitiveness.

\section{O bjectives and development of initial data diagnosis}

\subsection{Diagnosis objectives}

In order to conduct the diagnosis the following work objectives were established:

1. To set up an Expert Committee for the Project Direction, Knowledge Management, and Business Intelligence Development, employing scientific research techniques and tools.

2. To define an initial approach on the stages of the Project Management in Cuban design and construction companies from the study of their management regular practices.

3. To define an initial approach on the stages of the Business Intelligence and to conduct an exploratory analysis on the most relevant aspects.

4. To propose a Scientific Research Design to the Scientific Board.

\section{Development}

In order to solve the first objective, an Experts selection process took place; a group of specialists from all operational areas in the 18 companies was proposed, those corresponding to all possible segments involved with different processes, interests areas, professional or any other variable that qualifies them after the completion of an expertise survey (see Appendix \#1). The survey allowed the selection of candidates meeting the previously established requirements to set up an Expert Committee for the Project Direction, Knowledge Management, and Business Intelligence D evelopment.

For the selection of experts participating in this research, a procedure developed by Dr. MSc. María de Lourdes Artola (Delmás Magalys, Del Sol O rianna, 1998) 
was employed. It is notable the Expertise Index calculation (El) that will be used in the processing phase taking into consideration the report (García H. R., Cuétara S. L, 1996) about this subject.

The expert competence questionnaire, see Appendix \#1, is an extremely useful instrument in this stage, particularly because it captures information about the experience and know-how of a group of people related to the evaluation objective. This questionnaire layout together with the group of candidate experts, allows the capture of information useful to calculate the Expertise Index. It is divided in two parts. The first part gathers information about the features that identify the expert. In the second part, the candidate is requested to provide an appraisal regarding his labor background supporting his expert condition on the research study subject.

Before calculating the Expertise Index (EI), it was necessary to homogenize the values of different variables in this study.

72 proposed candidates, representative of different areas and work groups from 18 companies, were evaluated by determining their expertise index by means of Survey N r.1. Experts with an El $<0.4$ were disregarded and eventually only 65 candidates were considered.

\subsection{Survey Processing and Application (M iller and Freud, 2004)}

By using the Guidance interviews, Informative interviews, and different analysis methods Surveys \# 2 and 3 were created. See Annexes 2 and 3 that facilitated the approach to the initial data situation in these companies as far as Project Management and Business Intelligence Processes are concerned.

For the statistical processes in surveys \# 2 and 3 professional SPSS 10.0.6 software was employed by conducting a frequency descriptive and statistical analysis on the responses according to the evaluation scale, being in this case from 1 to 9 in order to achieve a higher average.

Responses from survey \#2, including evaluations between 7 and 9, demonstrate that these organizations have a strong culture regarding Project $M$ anagement techniques and tools, based on their own implementation methodology (Group of Authors of the Construction Ministry Cuba, 2006) as well as processes and they have achieved their service certification by the Buro Veritas, the Lloyd Register and the National Standardization Office of Cuba. 
Besides, for better displaying the obtained results, graphic outlet of frequency histograms were employed, as seen in the following pictures.

However the statistical process in survey \# 3, proved some other different situations as far as Business Intelligence Process is concerned, as shown by frequency histograms in below pictures.

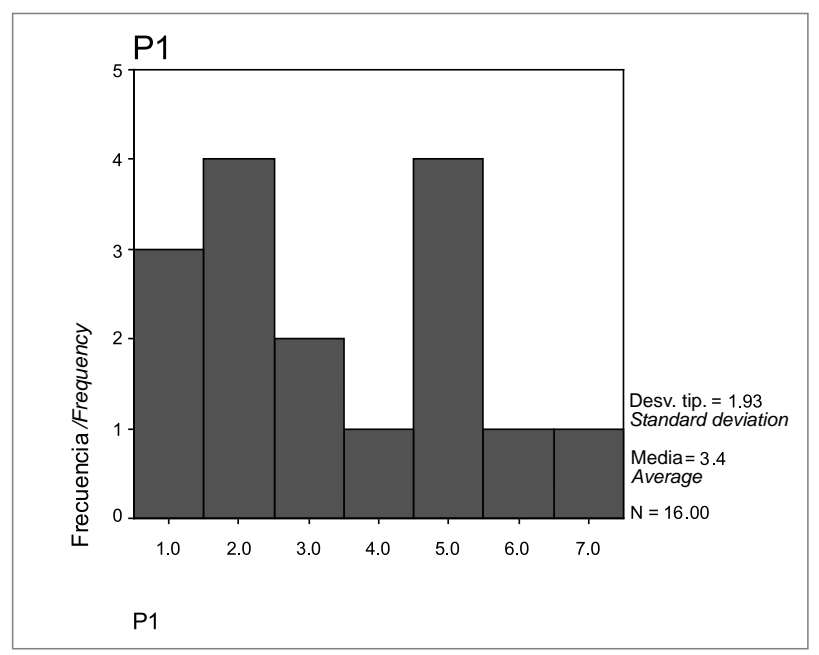

Figura 1. Resultados pregunta N 0.1 Figure 1. Results Inquiry \#1

$56 \%$ of the polled experts confirm to know few or nothing about Business Intelligence, while the remaining $44 \%$ claim to have some kind of knowledge about it.

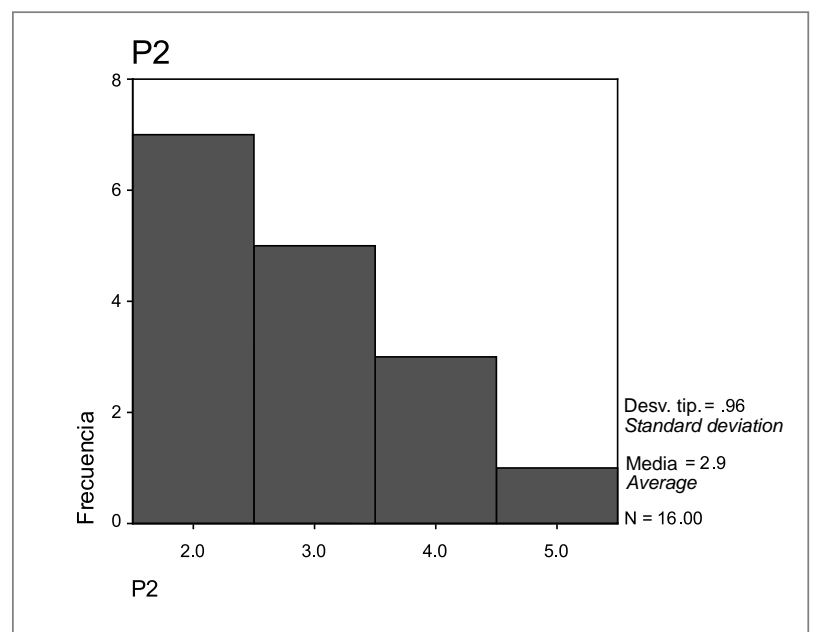

Figura 2. Resultados pregunta No.2

Figure 2. Results Inquiry \#2 
$75 \%$ of polled experts indicate that the degree of implementation of Business Intelligence Process is low inside the organization.

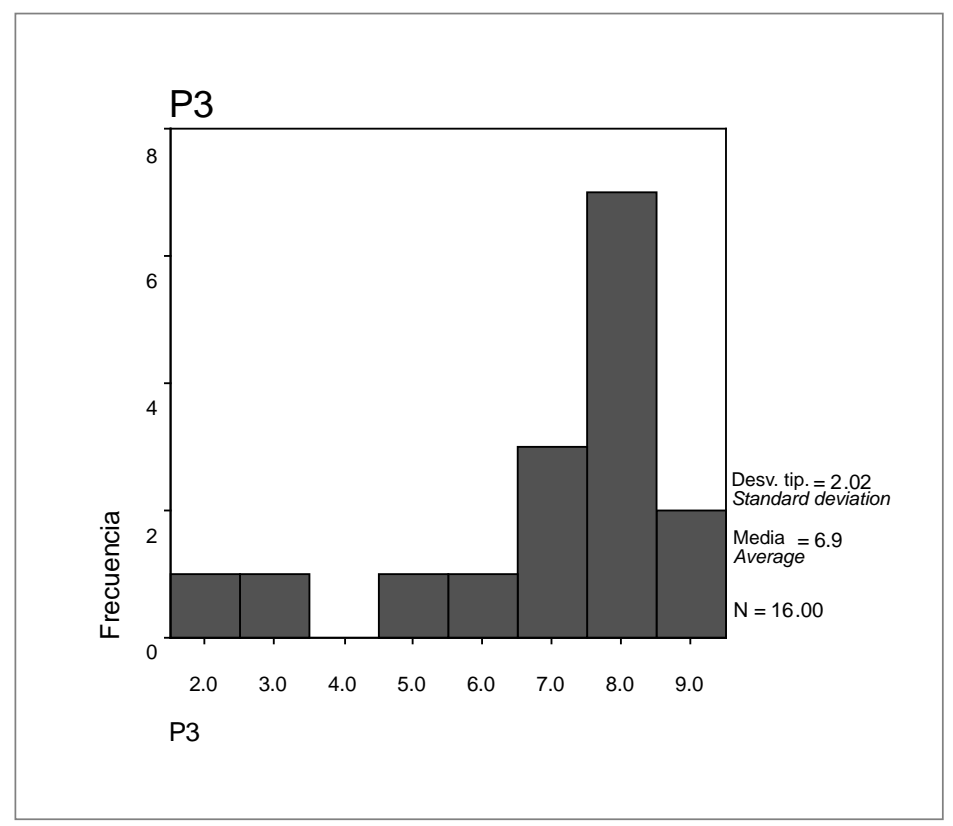

Figura 3. Resultados pregunta No.3.

Figure 3. Results Inquiry \#3

$81.4 \%$ of polled experts grant higher importance to the implementation of Knowledge Management, while a $12.3 \%$ considers it is not important.

Results Inquiry \#4, responses in decreasing order is the following.

- Improves the Competitive Intelligence - Innovative Capability relationship in their organization.

- Improves the Strategically Orientation in their organization.

- D etects competitive advantages.

- Implements tools facilitating and speeding up a better management of Productive Processes.

$82 \%$ of polled experts agreed on the first aspect, so we decided to deal it in depth. 


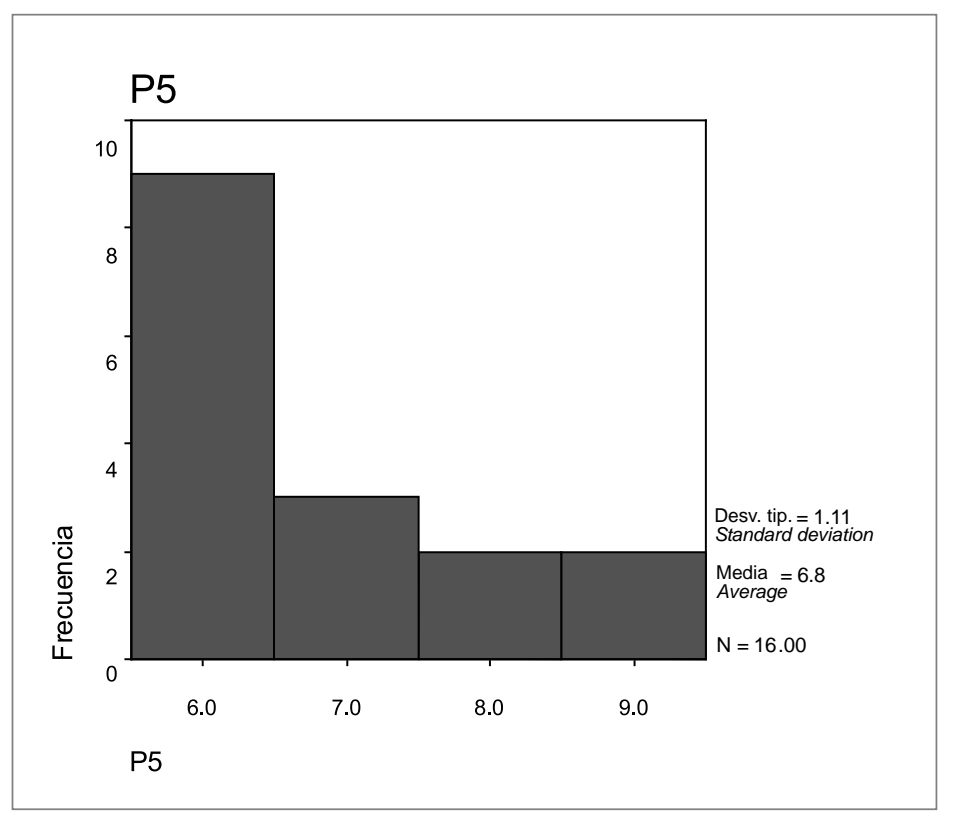

Figura 4. Resultados pregunta N 0.5 Figure 4. Results Inquiry \#5

$87.5 \%$ of polled experts consider themselves as highly motivated to face the culture change inside the organization.

Since $82 \%$ of polled experts considered that counting with a Business Intelligence Process will, in first place, lead to an improvement of the relationship Competitive Intelligence-Innovation Capability inside the organization, it was decided to conduct an exploratory analysis on this subject in order to deepen our knowledge on the current condition of Competitive Intelligence of the Design and Engineering companies in the Construction Sector in relation to their innovative capability.

- In effect, do they correctly use Competitive Intelligence to keep more competitive products?

- D oes the culture support Competitive Intelligence practices?

- Is the management administering the processes correctly?

Taking as a reference the method developed by Dr. David Güemes and Dr. Marisela Rodríguez from Quality and Manufacture Technological Center of Monterrey (Güemes and Rodríguez, 2007; Hernández, Fernández, Baptista, 1997), the following correlation was established obtaining results expressed in below graphs. 
Tabla 1. Correlación Inteligencia competitiva- capacidad de innovación en las empresas de diseño e ingeniería del sector de la construcción Table 1. Correlation competitive intelligence-innovation capability in design and engineering companies in the construction sector

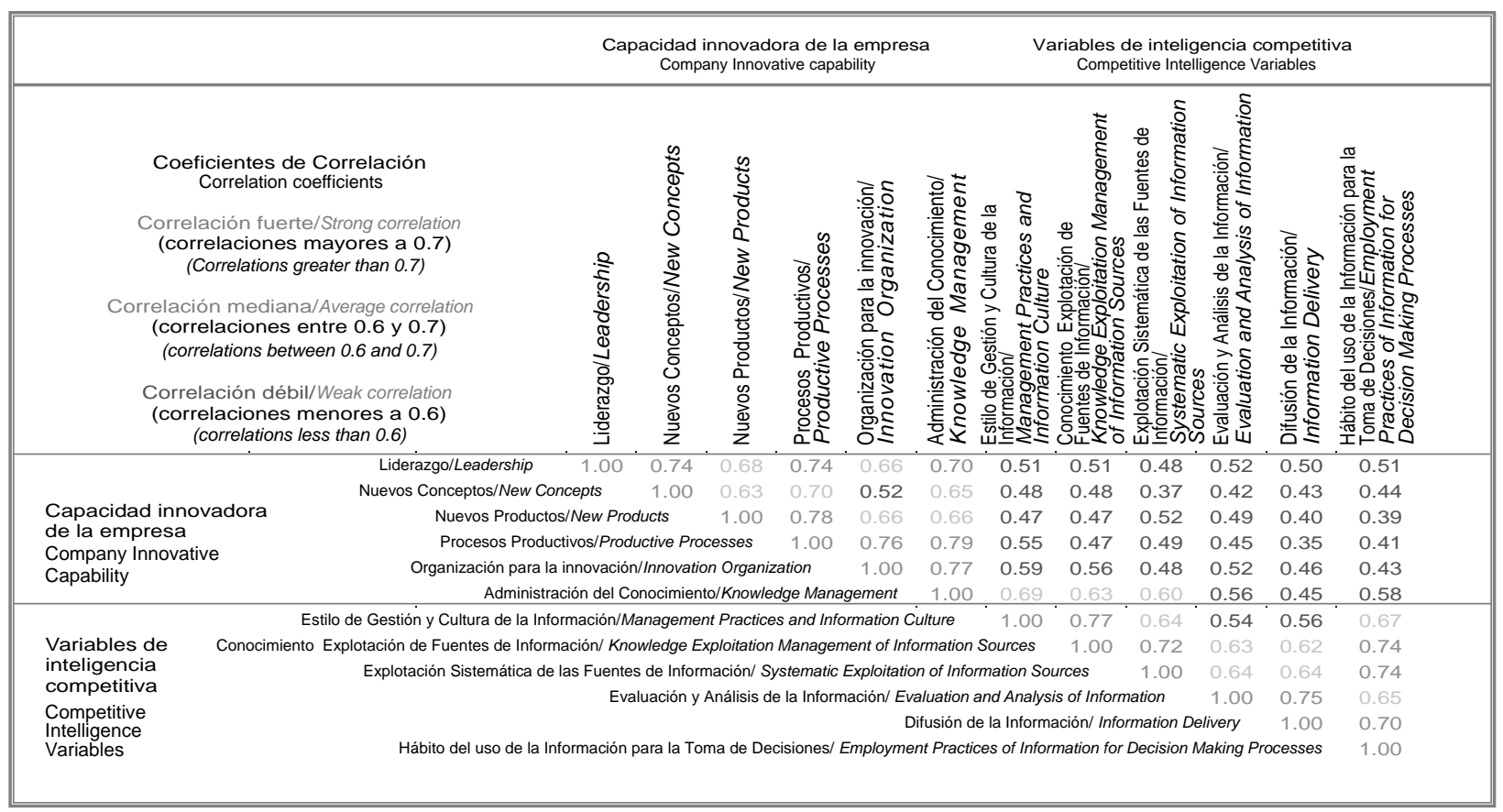

Analysis Results

- Businessmen's leadership has not influenced a better performance or competitive intelligence inside the companies yet.

- Companies do not own a process to create concepts from a systematic organization supported on the competitive intelligence practices yet.

- Although companies are considered as innovative organizations, they are not employing the whole potential from competitive intelligence to create better products.

- If companies are focused on the innovation/improvement of productive process, it is very likely they will be competing based on the cost, since products innovation usually takes place before innovation of production process and a motivation to improve the productive process is given by the advantages obtained from an economy of scale.

- Competitive intelligence does not directly influence innovation for the organization, including the practices of information uses for decision making processes.

- The knowledge management is the link that joints variables of innovative capabilities and competitive intelligence variables in companies, however the quality of knowledge management is still very poor in the organizations. 
- The organizations are acquainted with available information sources; however, information is not evaluated or delivered.

- Companies are in fact using the information systematically, though they have not discovered the need to link information to innovative opportunities.

- Companies do not use information systematically to feed their innovative capability.

- There is only a culture of delivering only what it was required $=$ " Analysis is conducted only on requested items and this information is delivered only to whom has demanded it"

- Information is delivered only to people requiring it. The innovation culture still does not exceed the paradigm "The one that possesses/accumulates more information is worthier than the one who shares/delivers more information"

- In fact, information is being used... but it is not dully employed for innovation (it is not used in function of increasing innovative capability).

Besides, a group activity was conducted by using a combination of techniques from Focus Groups and Force Fields in order to determine the elements that restrict and facilitate the change inside these organizations (Hernández, Fernández, Baptista, 1997) that began by designing a graph of the passage from present condition to the desired condition, which finally resulted as shown in the figure below.

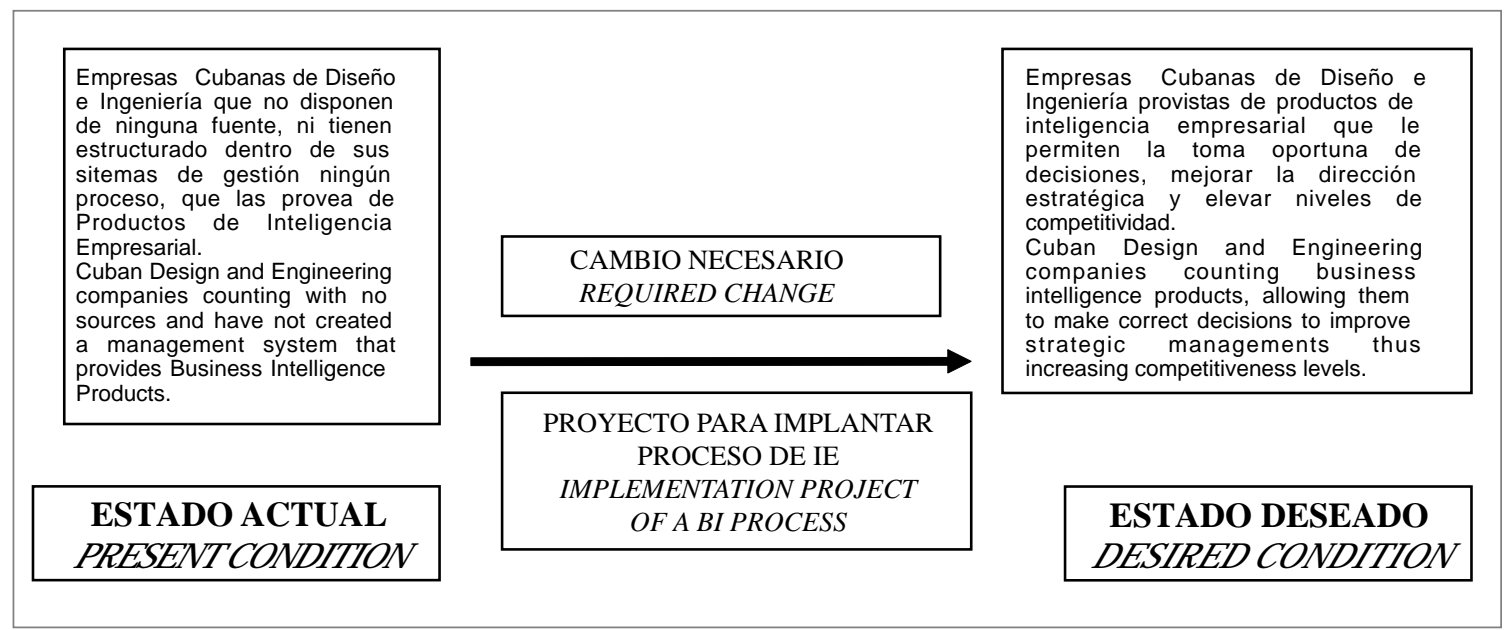

Figure 5. Gráfica del cambio Figure 5. Graphic of change 
O nce the situation is proposed, the experts were required to provide their opinions, restrictive forces (limitations) that restrain the achievement of the desired condition and the fostering forces (potentialities) that would facilitate the achievement of the desired condition. An analysis was developed in order to determine the forces arrangement. Fostering forces were kept and described as they were initially. Restrictive forces were grouped reaching a number of 10 .

According to the methodology of this exercise, one point is given to each restrictive and pulling force, then divided by two and finally added to the total amount. In this case, there are 10 restrictive forces; half is 5 , then $10+5=15$ total points for restrictive forces; those total points are distributed among each one of restrictive forces, individually, according to priority order assigned by every member of the group. The same operation was developed for fostering forces, so as to create a priority order among them in accordance with the group criteria.

The following tables show individual vote recorded by each member of the group.

Tabla 2. De votación para las fuerzas restringentes Table 2. Voting for restrictive forces

\begin{tabular}{||c|c|c|c|c|c|c|c|c|c|c|c||}
\hline \multirow{2}{*}{ Votantes/Voters } & \multicolumn{10}{c||}{ Preguntas/Inquiries } \\
\cline { 2 - 13 } & 1 & 2 & 3 & 4 & 5 & 6 & 7 & 8 & 9 & 10 & Total \\
\hline 1 & 0 & 2 & 5 & 0 & 3 & 0 & 0 & 0 & 2 & 3 & 15 \\
\hline 2 & 0 & 0 & 7 & 2 & 2 & 0 & 0 & 0 & 4 & 0 & 15 \\
\hline 3 & 1 & 3 & 3 & 1 & 2 & 1 & 1 & 1 & 1 & 1 & 15 \\
\hline 4 & 1 & 1 & 1 & 1 & 1 & 1 & 3 & 2 & 2 & 1 & 14 \\
\hline 5 & 2 & 3 & 1 & 1 & 2 & 1 & 1 & 1 & 2 & 1 & 15 \\
\hline 6 & 4 & 0 & 2 & 0 & 2 & 0 & 0 & 0 & 5 & 2 & 15 \\
\hline 7 & 3 & 2 & 1 & 1 & 3 & 1 & 1 & 1 & 1 & 1 & 15 \\
\hline 8 & 5 & 5 & 1 & 4 & 0 & 0 & 0 & 0 & 0 & 0 & 15 \\
\hline 9 & 1 & 1 & 1 & 2 & 3 & 1 & 3 & 1 & 1 & 1 & 15 \\
\hline 10 & 3 & 4 & 0 & 2 & 2 & 0 & 2 & 0 & 2 & 0 & 15 \\
\hline 11 & 2 & 0 & 3 & 0 & 3 & 1 & 2 & 2 & 1 & 1 & 15 \\
\hline 12 & 0 & 1 & 1 & 2 & 2 & 1 & 2 & 0 & 3 & 3 & 15 \\
\hline 13 & 3 & 2 & 2 & 1 & 2 & 1 & 1 & 0 & 1 & 2 & 15 \\
\hline Total & 25 & 24 & 28 & 17 & 27 & 8 & 16 & 8 & 25 & 16 & \\
\hline
\end{tabular}

Tabla 3. De votación para las fuerzas impulsoras Table 3. Voting for fostering forces

\begin{tabular}{|c|c|c|c|c|c|c|c|c|c|c|c||}
\hline \multirow{2}{*}{ Votantes/Voters } & \multicolumn{10}{|c||}{ Preguntas/Inquiries } \\
\cline { 2 - 13 } & 1 & 2 & 3 & 4 & 5 & 6 & 7 & 8 & 9 & 10 & Total \\
\hline 1 & 3 & 0 & 5 & 0 & 0 & 0 & 0 & 5 & 0 & 2 & 15 \\
\hline 2 & 0 & 4 & 5 & 2 & 0 & 0 & 0 & 1 & 0 & 3 & 15 \\
\hline 3 & 1 & 2 & 2 & 1 & 1 & 1 & 2 & 2 & 1 & 2 & 15 \\
\hline 4 & 1 & 1 & 2 & 1 & 1 & 1 & 1 & 3 & 1 & 2 & 14 \\
\hline 5 & 2 & 2 & 2 & 1 & 1 & 2 & 1 & 1 & 2 & 1 & 15 \\
\hline 6 & 0 & 0 & 0 & 0 & 0 & 5 & 2 & 3 & 2 & 3 & 15 \\
\hline 7 & 1 & 0 & 3 & 2 & 4 & 4 & 0 & 1 & 0 & 0 & 15 \\
\hline 8 & 1 & 1 & 3 & 3 & 3 & 0 & 4 & 0 & 0 & 0 & 15 \\
\hline 9 & 2 & 1 & 1 & 2 & 2 & 1 & 1 & 2 & 2 & 1 & 15 \\
\hline 10 & 2 & 2 & 1 & 1 & 2 & 0 & 2 & 1 & 1 & 3 & 15 \\
\hline 11 & 2 & 3 & 3 & 1 & 0 & 1 & 2 & 2 & 1 & 0 & 15 \\
\hline 12 & 4 & 1 & 1 & 0 & 3 & 0 & 2 & 3 & 0 & 1 & 15 \\
\hline 13 & 1 & 2 & 2 & 2 & 1 & 1 & 2 & 2 & 1 & 1 & 15 \\
\hline Total & 20 & 18 & 30 & 16 & 18 & 16 & 19 & 26 & 11 & 19 & \\
\hline
\end{tabular}


Forces were placed according to the score, starting with the highest; the first five of them are selected and go into a second phase of the exercise, which corresponds to the action plan to be performed so as to minimize the scope of restrictive forces and to boost fostering forces, then finally move from present condition to desired condition. The first five of each:

\section{Restrictive Forces:}

1. Lack of knowledge about the importance of Business Intelligence by the organization.

2. Absence or weakness of technological and prospective surveillance systems.

3. Lack of completion of data base records, collection of further information and integral connection between data bases.

4. Executive Staff shall support the specialists work developing information and knowledge management.

5. Lack of fluid internal communication, presence of duplicate interests and absence of support from involved staff.

\section{Pulling Forces:}

1. High performance of Information and Communication Techniques by the company.

2. It is an objective for Strategic Planning, for technological development by the Business Group and counts with the support from Top management.

3. Company staff is acquainted with the subject and is interested in its development.

4. High technical level of human capital resource.

5. Availability of a trained group in technological and prospective surveillance.

\section{Conclusions}

The outlined objectives were satisfactorily fulfilled since:

1. It was possible to measure the expertise level of candidates and the Expert Committee for Project and Knowledge Management and Business Intelligence was established.

2. Definition of a first approach on the Project Management, Business Intelligence and most relevant aspects in Cuban design and engineering companies from construction sector was achieved, considering daily managing practices and the use they make of created or acquired products and services, which prove the following: 
- It is a vital requirement for Cuban design and engineering companies associated to GEDIC to count, as soon as possible, with Project Models that enable the incorporation of Business Intelligence Processes to their daily practices.

- Such companies do not count with a Project Model to implement a BI Process, nor have acquired any other method among their systems providing Business Intelligence Products.

3. This diagnosis allowed an structural creation of a research design being jointly developed by the Higher Polytechnic Institute "José Antonio Echeverría" (ISPJAE), the U niversity of Matanzas "Camilo Cienfuegos (UMCC), the Projects Company of Architecture and Engineering of Matanzas (EMPAI), the Project Company of Civil Works (EPRO YIV), the Business G roup of Construction Design and Engineering under the Science and Technological Innovation Program for Development $M$ anagement conducted by the Construction Ministry in Cuba under the Construction Branch Program 03, from which specific results are expected.

a. Design of a Business Intelligence Process for D esign and Engineering Companies of construction sector in Cuba, where the following aspects will be clearly defined: Implementation of a functional structure by the companies, know-how to be acquired by the necessary staff and creation of work groups, kind of reports, regular recurrence and whom they are sent to; Budget of implementation, Process Objectives, main users: internal customers, the legal sources of $\mathrm{BI}$ information, required capabilities and methods to be followed; Mathematical methodologies, techniques and tools to be controlled, information systems enabling an effective use of intelligence products, to define the most suitable means to deliver $\mathrm{BI}$ products, to establish parameters to evaluate an effective BI Process support and functionality for Business Strategy.

b. Proposal of business intelligence products/services required by these Design and Engineering Companies in accordance with the competitive environment they are involved, classified by: 
- Type of Strategic Profiles: sector, company, product and personality.

- Type of Market Studies.

- Strategic Plans for the introduction of companies or products by a country or region.

- Evaluation of negotiations, mergers, purchases.

- Performance Evaluation.

- Identification of Competitors' hidden potential.

- Global studies on competitors.

c. Creation of a Project Model Manual to serve as guidance for researchers and executive staff involved in the improvement of Business $M$ anagement for the implementation of Business Intelligence Products to be delivered to other entities of similar characteristics in our country.

\section{Recommendations}

1. Interested entities should continue supporting and collaborating in the development of this research, which already got over the Modelling Design stage. The project and process are currently in the stage of Validation of Project Model and BI Process in order to fit the own characteristics of these entities in the construction sector.

2. Companies in the construction sector must consider the following in order to increase their competitiveness levels:

- Strategic Planning Models must be implemented taking into consideration the theories developed for Business Intelligence.

- Business Intelligence is a vital strategic asset for implementing suitable Strategic Management Processes.

- Emphasis must be focused in outlined strategies based on Business Intelligence Products, mainly on Competitive and Surveillance Intelligence.

- Strategic Management, favored by Business Intelligence products, will collaborate with a higher management performance and will enable the suitable decision making process.

- New strategic approaches of the third millennium, as well as the development of information and communication technologies, favor new working methods which must be analyzed for the competitive development of the company. 
Appendix \#1, survey \#1. On the expertise level of the sample

The Management Council of GEDIC requests your collaboration in order to determine your expertise level.

El Consejo de Dirección del GEDIC solicita de usted su colaboración para discernir su nivel de experticidadThe Management Council of GEDIC requests your collaboration in order to determine your expertise level.

- NOMBREY APELLIDOS/NAME AND LAST NAME:

- PROFESIÓ N/PRO FESSION :

- ESPECIALIDAD/ESPECIALIZACION:

- AÑOSDE GRADUADO/YEARS FROM GRADUATION :

- AÑOS DE EXPERIEN CIA LABO RAL/YEARS O F LABO R EXPERIENCE:

- AÑOS DE EXPERIEN CIA EN ESTA EM PRESA/YEARS OF EXPERIEN CE IN THIS COMPANY:

CLASIFIQUE EL NIVEL DE EXPERTICIA DEL TEM A/PLEASE CLASIFY THE LEVEL OF EXPERTISE O N THE SUBJECT:

1.DIRECCIÓN DE PROYECTOS/PROJECT MANAGMENT

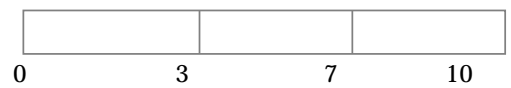

2.GESTION DE LA INFORMACIÓ N/INFORMATION MANAGEMENT

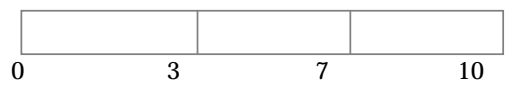

3.GESTIÓN DEL CONOCIMIENTO/KNOWLEDGEMENT MANAGEMENT

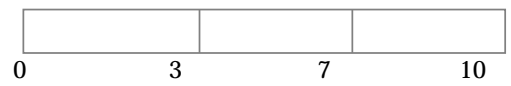

4.PRO CESO DE INTELIGEN CIA EM PRESARIAL/BU SINESS INTELLIGEN CE PRO CESS

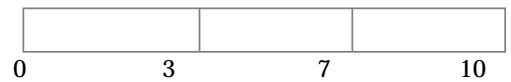

5.USO DE PRODUCTOS DE INTELIGENCIA EM PRESARIAL/U SE OF BU SINESS INTELLIGEN CE PRO DUCTS

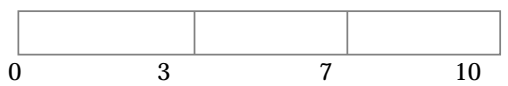

-0 A 3 BAJO NIVEL/LOW LEVEL

-3 A 7 NIVEL MEDIO/AVERAGE LEVEL

-7 A 10 ALTO NIVEL/HIGH LEVEL

Gracias por su colaboración/Thanks for your cooperation 


\section{Appendix \#2, Survey \#2}

The $M$ anagement Council of GEDIC requests your collaboration in order to determine your knowledge and culture level on Project Direction existing in your organizations.

For the evaluation of each criterion, please reply according to the following scale:

\begin{tabular}{|l|l|}
\hline Puntuación/Puntuation & Definición/D efinition \\
\hline 1 & Nada/None \\
\hline 3 & Poco/Few \\
\hline 5 & Moderadamente/Moderate \\
\hline 7 & Aceptable/Acceptable \\
\hline 9 & Alto/High \\
\hline $2,4,6,8$ & Para transar entre los valores anteriores/To mark in the middle of above values \\
\hline
\end{tabular}

1. ¿Que nivel de conocimiento tiene usted sobre Dirección de Proyectos?/W hat is your knowledge level about Project Direction?

\begin{tabular}{|l|l|l|l|l|l|l|l|l|}
\hline 1 & 2 & 3 & 4 & 5 & 6 & 7 & 8 & 9 \\
\hline & & & & & & & & \\
\hline
\end{tabular}

2. ¿Que grado de implantación considera usted que hay sobre el uso de las técnicas de Dirección de Proyectos en su organización?/In your opinion, what is the extent of Project Direction techniques implemented by your organization?

\begin{tabular}{|l|l|l|l|l|l|l|l|l|}
\hline 1 & 2 & 3 & 4 & 5 & 6 & 7 & 8 & 9 \\
\hline & & & & & & & & \\
\hline
\end{tabular}

3. ¿Q ue nivel de importancia da usted a la implantación de la Dirección de Proyectos en su O rganización?/W hat is the importance level you confer to the implementation of Project Direction in your organization?

\begin{tabular}{|l|l|l|l|l|l|l|l|l|}
\hline 1 & 2 & 3 & 4 & 5 & 6 & 7 & 8 & 9 \\
\hline & & & & & & & & \\
\hline
\end{tabular}

4. ¿Q ué procesos cree usted que serán mejorados con la implantación de un Sistema que permita trabajar por Proyectos en su organización?/Which are the processes you consider will be improved upon the implementation of a project system in your organization?

Mejora la orientación Estratégica de su organización/To strategically improve O rientation of the organization

Mejora la introducción de la Innovación en su organización/To improve Innovation Introduction in the organization

Mejora la introducción de Transferencias Tecnológicos en su organización/To improve the Introduction of Technological Transfer in the organization

Establecer herramientas que faciliten y agilicen una mejor gestión de los Procesos Productivos/To create tools facilitating and speeding up a better management of productive processes

5. ¿Está motivado usted para este cambio de cultura organizacional?/Are you motivated with this cultural change in the organization?

\begin{tabular}{|l|l|l|l|l|l|l|l|l|}
\hline 1 & 2 & 3 & 4 & 5 & 6 & 7 & 8 & 9 \\
\hline & & & & & & & & \\
\hline
\end{tabular}

Explique las causas/Please explain your reasons

¡Muchas Gracias por su colaboración!/Thanks for your cooperation! 


\section{Appendix \#3 - Survey \#3}

The Management Council of GEDIC requests your collaboration in order to determine your knowledge and culture level on Business Intelligence Process (BI) existing in your organizations.

For the evaluation of each criterion, please reply according to the following scale:

\begin{tabular}{||l|l||}
\hline Puntuación/Puntuation & Definición/D efinition \\
\hline 1 & Nada/N one \\
\hline 3 & Poco/Few \\
\hline 5 & Moderadamente/M oderate \\
\hline 7 & Aceptable/Acceptable \\
\hline 9 & Alto/High \\
\hline $2,4,6,8$ & Para transar entre los valores anteriores/To mark in the middle of above values \\
\hline
\end{tabular}

6. ¿Qué nivel de conocimiento tiene usted sobre el Proceso de IE?/W hat is your knowledge level about BI Process?

\begin{tabular}{|l|l|l|l|l|l|l|l|l|}
\hline 1 & 2 & 3 & 4 & 5 & 6 & 7 & 8 & 9 \\
\hline & & & & & & & & \\
\hline
\end{tabular}

7. ¿Q ué grado de implantación considera usted que hay del Proceso de IE en su organización?/In your opinion, what is the extent of implementation of BI Process in your organization?

\begin{tabular}{|l|l|l|l|l|l|l|l|l|}
\hline 1 & 2 & 3 & 4 & 5 & 6 & 7 & 8 & 9 \\
\hline & & & & & & & & \\
\hline
\end{tabular}

8. ¿Q ué nivel de importancia da usted a la implantación del Proceso de IE en su O rganización?/W hat is the importance level you confer to the implementation of BI Process in your organization?

\begin{tabular}{|l|l|l|l|l|l|l|l|l|}
\hline 1 & 2 & 3 & 4 & 5 & 6 & 7 & 8 & 9 \\
\hline & & & & & & & & \\
\hline
\end{tabular}

9. ¿Q ué procesos cree usted que serán mejorados con la implantación de un Sistema que Gestione el Conocimiento?/Which are the processes you consider will be improved upon the implementation of a Knowledge Management System in your organization?

Mejora la orientación estrategica de su organización/To strategically improve O rientation of the organization Mejora la relación Inteligencia Competitiva - Innovación en su organización/To improve Competitive Intelligence - Innovation in the organization

Detectar las ventajas competitivas/To find out competitive advantages

Establecer herramientas que faciliten y agilicen la toma oportuna de decisiones/To create tools facilitating and speeding up appropriate decision making processes

10. ¿Está motivado usted para este cambio de cultura organizacional?/Are you motivated with this cultural change in the organization?

\begin{tabular}{|l|l|l|l|l|l|l|l|l|}
\hline 1 & 2 & 3 & 4 & 5 & 6 & 7 & 8 & 9 \\
\hline & & & & & & & & \\
\hline
\end{tabular}

Explique las causas/Please explain your reasons

¡Muchas Gracias por su colaboración!/Thanks for your cooperation! 


\section{Referencias / References}

Heredia R. (1999), “Dirección Integrada de Proyecto -Project Management-", Sección de Publicaciones de la Escuela Técnica Superior de Ingenieros Industriales de la Universidad Politécnica de Madrid. 2da Edición 1995 o 3ra Edición 1999, Periódico Granma (1997), Resolución Económica del V Congreso del Partido Comunista de Cuba, Periódico Granma, La Habana, noviembre 1997.

Rodríguez Peña L. (1998), Adecuación de la DIP a las condiciones cubanas en el Sector de la Construcción Tesis de Doctorado. ISPJAE. Martino L (1985) Administración y control de proyectos

Güemes D. y Rodríguez M. (2007) Centro de Calidad y Manufactura Tecnológico de Monterrey,Articulo publicado en htt/ www. intempres"2007

Hernández R., Fernández C. y Baptista P. (1997), Metodología de la Investigación, McGraw-Hill, México Miller Freud (2004), Probabilidad y Estadística para Ingenieros; M.Graw Hill, Quinta Edición

Colectivo de Autores del Ministerio de la Construcción de Cuba (2006), Expediente del Proyecto de Investigación M etodología para el diseño e implantación de servicios basados en la Dirección Integrada de Proyectos en empresas cubanas de diseño e ingeniería" 